\title{
Plant growth regulator losses in cotton as affected by adjuvants and rain
}

\author{
Perdas de reguladores de crescimento do algodoeiro em função de adjuvante e de chuva simulada
}

Fábio Rafael Echer ${ }^{I^{*}}$ Ciro Antonio Rosolem ${ }^{\mathrm{I}}$

\begin{abstract}
Most of Brazilian cotton is produced in regions where annual rainfall exceeds $1,500 \mathrm{~mm}$, hence plant growth regulators (PGR) may be washed from the leaves before being absorbed. The objective of this research was to evaluate mepiquat chloride and chlormequat chloride washing from cotton leaves by rains occurring at different moments post spraying. The experiment was conducted in a greenhouse. Both PGR were sprayed to cotton at pin-head square at $15 \mathrm{~g} \mathrm{ha} \mathrm{h}^{-1}$ a.i. with and without a silicon-based adjuvant, and simulated rains were applied at 0, 0.75, 1.5, 3.0, 6.0, 12.0 and 24 hours after spraying, plus a control without rainfall. Addition of silicon adjuvant increased PGR uptake. Rainfall occurring up to 24 hours after spraying resulted in some PGR loss from cotton leaves, mainly in the absence of the adjuvant. The decreased uptake implies that in order to achieve the desired level of growth reduction, at least a fraction of the original PGR rate should be reapplied.
\end{abstract}

Key words: Gossypium hirsutum, Plant height, Mepiquat chloride, Chlormequat Chloride, rainfall.

\section{RESUMO}

Nas maiores regiões algodoeiras no Brasil, chove mais de $1.500 \mathrm{~mm}$ anuais, existindo risco de ocorrer lavagem de reguladores de crescimento aplicados às folhas do algodoeiro, antes que sejam absorvidos. $O$ objetivo deste trabalho foi avaliar a lavagem dos reguladores de crescimento cloreto de mepiquat e cloreto de chlormequat de folhas de algodoeiro por chuva, ocorrendo em diferentes momentos após a aplicação. O trabalho foi realizado em casa de vegetação. Ambos os reguladores foram aplicados no aparecimento do primeiro botão floral, na dose de $15 \mathrm{~g} \mathrm{ha} \mathrm{g}^{-1}$ de i.a. com e sem adjuvante siliconado, e chuva simulada foi aplicada aos 0 , 0,$75 ; 1,5 ; 3,0 ; 6,0 ; 12,0$ e 24 horas após a aplicação dos reguladores, mais um tratamento sem chuva. A adição de adjuvante siliconado melhorou a absorção dos produtos. A ocorrência de chuva até mesmo 24 horas após a aplicação dos reguladores pode lavar parte dos produtos das plantas de algodoeiro, com maior intensidade para o tratamento sem adjuvante. A redução da absorção do produto leva à necessidade de reaplicá-lo para que possa haver a sua ação, sem comprometer sua função.

Palavras-chave: Gossypium hirsutum, regulador vegetal, Cloreto de Mepiquat, Cloreto de Chlormequat, chuva.

\section{INTRODUCTION}

Rank growth is often observed in cotton (Gossypium hirsutum L.), resulting in tall, densely foliated plants, which prevents solar radiation penetration in the shoots, with negative impacts on yields (LAMAS, 2001). Plant regulators are used to manipulate cotton plant architecture to prevent this loss. The plant growth regulators most widely used in Brazil to control plant height are mepiquat chloride (MC) and chlormequat chloride (CC). These are systemic products that inhibit gibberellic acid biosynthesis. Therefore, cell elongation is decreased, as well as growth and foliar area (REDDY et al., 1996). The potential benefits of these regulators are: improved plant architecture, increased fruit retention in the first positions, early fruit opening, higher harvesting efficiency and higher quality (SOUZA; ROSOLEM, 2007). According to REDDY et al. (1990) growth

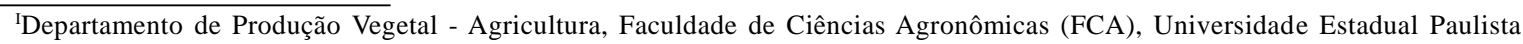
(UNESP), Campus de Botucatu, CP 237, 18610-307, Botucatu, SP, Brasil. E-mail: fabioecher@gmail.com. *Autor para correspondência. 
regulator application results in more compact plants, with a ratio of reproductive to vegetative dry matter larger than one, and this ratio has a positive correlation with cotton yields.

The time in which PGRs are applied to cotton in Brazil coincides with a high rainfall period, usually from December to February. Therefore, there is a high risk that the product may be washed away by rain before plant uptake. Hence, it would be necessary to reapply the amount lost in order to achieve the expected effect in plant growth control. SOUZA \& ROSOLEM (2007) observed that $5 \mathrm{~mm}$ of rainfall occurring $30 \mathrm{~min}$ after MC application was enough to wash it from cotton leaves, resulting in a lower control over the plant's growth. In this case, it was necessary to reapply from 20 to $40 \%$ of the initial rates of 15 and $30 \mathrm{~g}$ i.a. ha ${ }^{-1}$, respectively to control plant high. Losses of Mepiquat Chloride from cotton plants ranged between 52 and $28 \%$ with rains occurring from immediately after to up to 32 hours after spraying (MATEUS et al., 2004). However, the use of adjuvants may improve plant uptake, reducing losses, but there are no conclusive studies on the use of adjuvants to improve growth regulators uptake by cotton as affected by rainfall. Organic-silicon based adjuvants can be absorbed by the stomata and the cuticles, given the low surface tension values of the spraying solution. These effects depend on the active ingredient used and on the characteristics of the epicuticle waxes (ROSOLEM, 2002).

The objective of this research was to evaluate $\mathrm{MC}$ and $\mathrm{CC}$ washing from cotton leaves when applied with and without a silicon adjuvant, as affected by simulated rains occurring at different moments after spraying.

\section{MATERIAL AND METHODS}

A greenhouse experiment was conducted in Botucatu, SP, Brazil ( $22^{\circ} 51^{\prime} \mathrm{S}, 48^{\circ} 26^{\prime} \mathrm{O}$ ) in $12 \mathrm{~L}$ pots with a Rhodic Ferralsol (FAO, 2006). Each pot was considered an experimental unit, with 4 replications. The soil, after liming and fertilization, showed $\mathrm{pH}$ $\left(\mathrm{CaCl}_{2}\right) 5.60 ; 17.8 \mathrm{~g} \mathrm{dm}^{-3}$ of M.O.; $93 \mathrm{mg} \mathrm{dm}^{-3}$ of P (resin); 2.7,31.3 and $12.1 \mathrm{mmol}_{\mathrm{c}} \mathrm{dm}^{-3}$ of $\mathrm{K}, \mathrm{Ca}$ and $\mathrm{Mg} ; 31.3 \mathrm{mmol}_{\mathrm{c}}$ $\mathrm{dm}^{-3}$ of $\mathrm{H}+\mathrm{Al}$ (RAIJ et al., 2001). Each pot received five seeds of cotton (Gossypium hirsutum, cv. 'Delta OPAL'), pre-germinated for 36 hours at $30^{\circ} \mathrm{C}$. From the appearance of the first pair of true leaves, V2 (MARUR \& RUANO, 2001) to flowering, it was applied $200 \mathrm{ml}$ of half strength Hoagland's solution per pot weekly. After flowering, full strength solution was applied every week. Mepiquat chloride (MC) and chlormequat chloride (CC) were applied 30DAE at pinhead square or B1 stage
(MARUR \& RUANO, 2001), at a rate of $15.0 \mathrm{~g} \mathrm{ha}^{-1}$ (a.i.), with a solution volume of $1501 \mathrm{ha}^{-1}$. The spraying solution received or not a silicon adjuvant $\left(\right.$ Silwet $\left.^{\circledR}\right)$ at $0.1 \%$. Plants were then subjected to $30 \mathrm{~mm}$ simulated rainfalls at $0,0.75 ; 1.5,3.0,6.0,12.0$ and 24 hours after spraying plus one treatment without rain. Briefly, the rainfall simulation equipment (GARCIA et al., 2010) was composed of a 3-m high, 2-m wide metal frame with a carriage coupled $2.5 \mathrm{~m}$ overhead. A rainfall simulator bar with 3 high-flow nozzles (TK-SS-20) $0.5 \mathrm{~m}$ apart was fixed onto the carriage. Rainfall simulation was produced with a working pressure of $0.81 \mathrm{MPa}$ and displacement speed of $0.0526 \mathrm{~m} \mathrm{~s}^{-1}$, resulting the application of a $2.5 \mathrm{~mm}$ rainfall each pass. The experimental units were arranged along the simulator according to the spacing normally used in cotton plantations $(0.90 \mathrm{~m})$. Pots remained on the floor and the sprayer was $1.75 \mathrm{~m}$ above. Cotton plants were grown up to 24 days after spraying, and harvested at full bloom, with bolls beginning to develop. Plant height was recorded before PGR application and then at 3-day intervals. During the experiment, maximum and minimum air temperatures were recorded in order to calculate the accumulated degree-day (DD). The average temperature after PGR application was $27.7^{\circ} \mathrm{C}$. The accumulated $\mathrm{DD}$ was calculated using the equation $\mathrm{DD}=(\operatorname{Tmax}+\mathrm{Tmin}) / 2-15$, where $\mathrm{Tmax}$ is the maximum temperature, Tmin is the minimum temperature and 15 is the base temperature. Plant growth rates were estimated using the first derivative of the equations fit to the growth curves.

At harvest, the number of reproductive and vegetative branches, number of reproductive structures, leaf area and dry matter yields were determined. Leaf area was measured using an LI-3100 area meter (Li-Cor, Lincoln, NE, USA). To determine dry matter, plants were oven dried for 72 hours at $60^{\circ} \mathrm{C}$. The PGR loss by rain was estimated using plant growth at 250DD after spraying, and the following equation was used: $\mathrm{L}=[1-(\mathrm{Gcon} / \mathrm{G}$ treat $)] \mathrm{xR}$; where: $\mathrm{L}=$ Amount lost, in $\mathrm{ml} \mathrm{ha}^{-1}$; Gcon = growth of control plants (treatment without rain), in $\mathrm{cm}$; Gtreat $=$ growth of treatments in $\mathrm{cm} ; \mathrm{R}=\mathrm{PGR}$ rate in $\mathrm{ml} \mathrm{ha}^{-1}$.

PGR retention in cotton leaves was estimated by running a parallel test. In summary, a solution with a dye concentration of $3000 \mathrm{mg} \mathrm{L}^{-1}$ was applied to plants, and the leaves were collected and washed, and the leaf area was determined. The washing solution was collected and absorbance readings were taken on a spectrum-photometer, thus estimating the amount of product present in the rinse water and consequently, how much was retained in the leaves.

The experimental design was a factorial $2 \times 7+1$ (absence and presence of adjuvant and 7 times) plus a control without rain, in complete randomized blocks, with 
4 replications. Means were compared using an LSD test $(\mathrm{P}<0.05)$. Regression curves were adjusted for plant growth plotted against the accumulated temperature.

\section{RESULTS AND DISCUSSION}

There were fewer reproductive branches in plants not receiving rain as compared with those receiving rain immediately after spraying (Table 1$)$. The results observed when no rain was applied confirm the reported effect of $\mathrm{MC}$ reducing cotton yields in the higher plant nodes (COOK \& KENNEDY, 2000). In spite of some significant differences, the effect of the adjuvant on the number of reproductive branches was not consistent over the time from spraying to simulated rain (Table 2). A decrease in the number of reproductive branches may result in decreased yield because there will be probably fewer fruits, but, in general, the number of reproductive structures was not affected by the adjuvant or time without rain (Table 1). ZHAO \& OOSTERHUIS (2000) concluded that MC did not increase the number of reproductive structures (bolls per square meter). In the present experiment, regardless of PGR washing from the cotton leaves by simulated rain, there was also no effect on the number of reproductive structures 64 days after emergence
(350DD). Conversely, BILES \& COTHREN (2001) observed that MC increased the number of flowers 35 days after the first flower. Hence, the PGR effect on cotton flowering/fruiting control is controversial and depends on the environment.

Cotton leaf area was decreased by $\mathrm{MC}$ in association with the adjuvant when rain was applied 12 hours after spraying. However, when the regulator was applied without adjuvant, the decrease in leaf area was observed only in plants remaining 24 hours without rain, showing that the adjuvant improved PGR uptake (Table 1). Plants that received simulated rain 45 minutes after CC plus adjuvant application had smaller leaves (Table 2). Without adjuvant, MC application resulted in higher shoot dry matter up to $12 \mathrm{~h}$ without rain. However, there was no effect of the adjuvant or time without rain after the application of CC. Contrary to what was observed in this paper, MATEUS et al. (2004) found no effect of time without rain on dry matter yields of plants grown up to $425 \mathrm{DD}$, and this may have occurred given the longer time of the experiment, which may have faded the effect of the treatments.

When rain was simulated right after spraying (Oh) there were no differences in plant growth due to the adjuvant (Figure 1-A1), showing that it did not prevent $\mathrm{MC}$ washing from cotton leaves at this moment. However,

Table 1 - Number of reproductive branches (sympodial), reproductive structures, aborted reproductive structures, foliar area and dry matter mass for cotton plants at 64DAE treated with Mepiquat chloride based growth regulator as a function of the use of adjuvant at the moment of application of the regulator and the time without rain after the application

\begin{tabular}{|c|c|c|c|c|c|c|c|c|}
\hline Adjuvant/Rain & $0 \mathrm{~h}$ & $45 \mathrm{~min}$ & $1,5 \mathrm{~h}$ & $3 \mathrm{~h}$ & $6 \mathrm{~h}$ & $12 \mathrm{~h}$ & $24 \mathrm{~h}$ & Without rain \\
\hline & \multicolumn{8}{|c|}{---or } \\
\hline With adj. & 13.3 & 11.9 & 11.5 & 12.4 & 12.1 & 11.5 & 11.4 & 11.9 \\
\hline Without adj. & 13.6 & 12.5 & 13.0 & 12.5 & 12.8 & 12.9 & 12.0 & 11.4 \\
\hline \multirow[t]{2}{*}{ DMS / CV(\%) } & \multicolumn{8}{|c|}{$1.2 * / 9.9$} \\
\hline & & & & nber of $\mathrm{F}$ & active st & ------ & 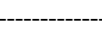 & ---- \\
\hline With adj. & 16.0 & 14.6 & 13.8 & 14.3 & 13.9 & 14.5 & 15.9 & 13.9 \\
\hline Without adj. & 16.5 & 14.6 & 15.4 & 15.9 & 15.9 & 15.0 & 15.6 & 13.6 \\
\hline \multirow[t]{2}{*}{ DMS / CV(\%) } & \multicolumn{8}{|c|}{$3.6 * / 24.5$} \\
\hline & & & 1---- & of reprc & structu & rted--- & & \\
\hline With adj. & 1.3 & 1.0 & 1.4 & 1.3 & 2.0 & 1.0 & 1.9 & 1.6 \\
\hline Without adj. & 1.9 & 1.6 & 1.5 & 1.0 & 1.4 & 1.0 & 1.4 & 1.4 \\
\hline \multirow[t]{2}{*}{ DMS / CV(\%) } & \multicolumn{8}{|c|}{$1.0 * / 74.8$} \\
\hline & & & & -----Fol & $\left(\mathrm{cm}^{2}\right)-$ & & & \\
\hline With adj. & 7025.6 & 6360.7 & 6112.7 & 6084.5 & 6106.9 & 5485.7 & 5067.7 & 3640.8 \\
\hline Without adj. & 6033.8 & 6220.2 & 5806.1 & 5132.9 & 5588.9 & 5062.6 & 3449.3 & 6222.1 \\
\hline \multirow[t]{2}{*}{ DMS / CV(\%) } & \multicolumn{8}{|c|}{$1261.8 * / 15.9$} \\
\hline & & & & Total di & r mass & 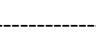 & & \\
\hline With adj. & 89.1 & 75.9 & 72.8 & 76.5 & 76.2 & 68.4 & 74.6 & 37.5 \\
\hline Without adj. & 110.4 & 103.5 & 104.1 & 89.8 & 87.6 & 95.0 & 80.8 & 49.6 \\
\hline DMS / CV(\%) & \multicolumn{8}{|c|}{$19.5 * / 22.4$} \\
\hline
\end{tabular}


Table 2 - Number of reproductive branches (sympodial), reproductive structures, aborted reproductive structures, foliar area and dry matter mass for cotton plants at 64DAE treated with Chlormequat chloride based growth regulator as a function of the use of adjuvant at the moment of application of the regulator and the time without rain after the application

\begin{tabular}{|c|c|c|c|c|c|c|c|c|}
\hline Adjuvant/Rain & $\mathrm{Oh}$ & $45 \mathrm{~min}$ & $1,5 \mathrm{~h}$ & $3 \mathrm{~h}$ & $6 \mathrm{~h}$ & $12 \mathrm{~h}$ & $24 \mathrm{~h}$ & Without rain \\
\hline \multirow{4}{*}{$\begin{array}{l}\text { With adj. } \\
\text { Without adj. } \\
\text { DMS / CV(\%) }\end{array}$} & \multicolumn{8}{|c|}{ - } \\
\hline & 12.8 & 11.8 & 13.5 & 13.8 & 12.1 & 11.9 & 10.8 & 12.8 \\
\hline & 13.6 & 13.9 & 14.5 & 13.9 & 12.5 & 13.4 & 13.4 & 12.3 \\
\hline & \multicolumn{8}{|c|}{$1.7 * / 13.0$} \\
\hline & & & & mber of & Ictive st & s---_-_- & & --_--- \\
\hline \multirow{4}{*}{$\begin{array}{l}\text { With adj. } \\
\text { Without adj. } \\
\text { DMS / CV(\%) }\end{array}$} & 16.5 & 15.4 & 16.4 & 18.6 & 15.9 & 11.5 & 15.5 & 19.9 \\
\hline & 17.8 & 17.9 & 18.4 & 20.8 & 16.1 & 17.0 & 16.2 & 16.9 \\
\hline & \multicolumn{8}{|c|}{$4.3 * / 25.5$} \\
\hline & & & - & of repr & e struct & rted--- & --- & -------- \\
\hline \multirow{4}{*}{$\begin{array}{l}\text { With adj. } \\
\text { Without adj. } \\
\text { DMS / CV }(\%)\end{array}$} & 2.5 & 1.5 & 1.8 & 1.3 & 1.6 & 2.3 & 2.4 & 1.6 \\
\hline & 2.6 & 2.3 & 3.3 & 2.8 & 1.5 & 1.5 & 1.8 & 2.1 \\
\hline & \multicolumn{8}{|c|}{$1.4 * / 70.3$} \\
\hline & & & & $---F o$ & $\left(\mathrm{~cm}^{2}\right)-$ & 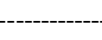 & - & - \\
\hline With adj. & 5670.8 & 5581.5 & 5441.5 & 6614.8 & 5674.5 & 5362.5 & 4681.3 & 5235.3 \\
\hline Without adj. & 6028.0 & 7199.3 & 6588.0 & 6169.8 & 5810.0 & 5804.8 & 5433.0 & 5372.0 \\
\hline \multirow[t]{2}{*}{$\mathrm{DMS} / \mathrm{CV}(\%)$} & \multicolumn{8}{|c|}{$1213.3 * / 14.7$} \\
\hline & & & & -Total d & er mass & & & \\
\hline With adj. & 80.3 & 83.3 & 65.3 & 92.3 & 68.0 & 76.0 & 75.5 & 97.0 \\
\hline Without adj. & 75.5 & 92.8 & 79.8 & 85.0 & 75.5 & 70.8 & 79.5 & 86.0 \\
\hline DMS / CV(\%) & \multicolumn{8}{|c|}{$23.4 * / 20.5$} \\
\hline
\end{tabular}

* Significant, DMS test $(P<5 \%)$. ns: not significant

as rainfall was delayed for 45 minutes or more, plant growth was higher in treatments without adjuvant (Figure 1-A2). Therefore, the addition of a silicon adjuvant to the spray solution improved regulator persistence and/ or uptake by cotton. This resulted in better plant height control, as shown by the smaller angular coefficients of the plant growth equations with adjuvant up to $6 \mathrm{~h}$ without rain (Figure 1-A1 and A2). The CC effect on growth control was stronger when associated with the adjuvant, irrespective of the time of rain (Figure 1-B1). However, without adjuvant, plant growth was reduced only after hours without rain. So, the effect of a silicon adjuvant improving PGR uptake was higher for $\mathrm{CC}$ than for MC (Figure 1).

Plant final height was decreased by MC as rainfall was delayed, and when the rain was applied after the $24^{\text {th }}$ hour from spraying there was no further effect, since the plants became as tall as those without rain (Table 3). Also, the adjuvant led to plant heights similar to those observed in the treatment without rain at 45 minutes after spraying, but without adjuvant this was only observed 6 hours after spraying. For CC, the absence of rain up to the $6^{\text {th }}$ hour after spraying was enough to control plant height, which was similar to plants that received no rain (Table 3). Plant growth was lower and more uniform when the adjuvant was used with CC as compared with no adjuvant. In spite of the differences in efficiency observed for growth regulators on plant height at 350 degrees day in this paper, final heights at harvest time tended to be similar because, as shown in most studies reported, there is no difference in final plant height when $\mathrm{MC}$ or $\mathrm{CC}$ are used (LAMAS, 2001). Regarding the time without rain after the application of MC without adjuvant, MATEUS et al. (2004) reported that final plant height was higher when rain was applied immediately following MC spraying than for plants not receiving rain or that received rain after the $32^{\text {nd }}$ hour after MC application, a result similar to ours.

The concentration of $\mathrm{MC}$ and $\mathrm{CC}$ in cotton leaves increased with time without rain (Figure 2A). The use of a silicon adjuvant decreased the uptake rate (lower angular coefficient) but increased PGR concentrations in leaves when rainfall was applied up to $12 \mathrm{~h}$ after spraying for MC and $18 \mathrm{~h}$ for CC (Figure 2B). Even though these are different experiments conducted simultaneously, CC without adjuvant showed higher washing, in nominal values, as compared with MC, resulting in lower PGR leaf concentrations and eventually lower plant height control. However, 


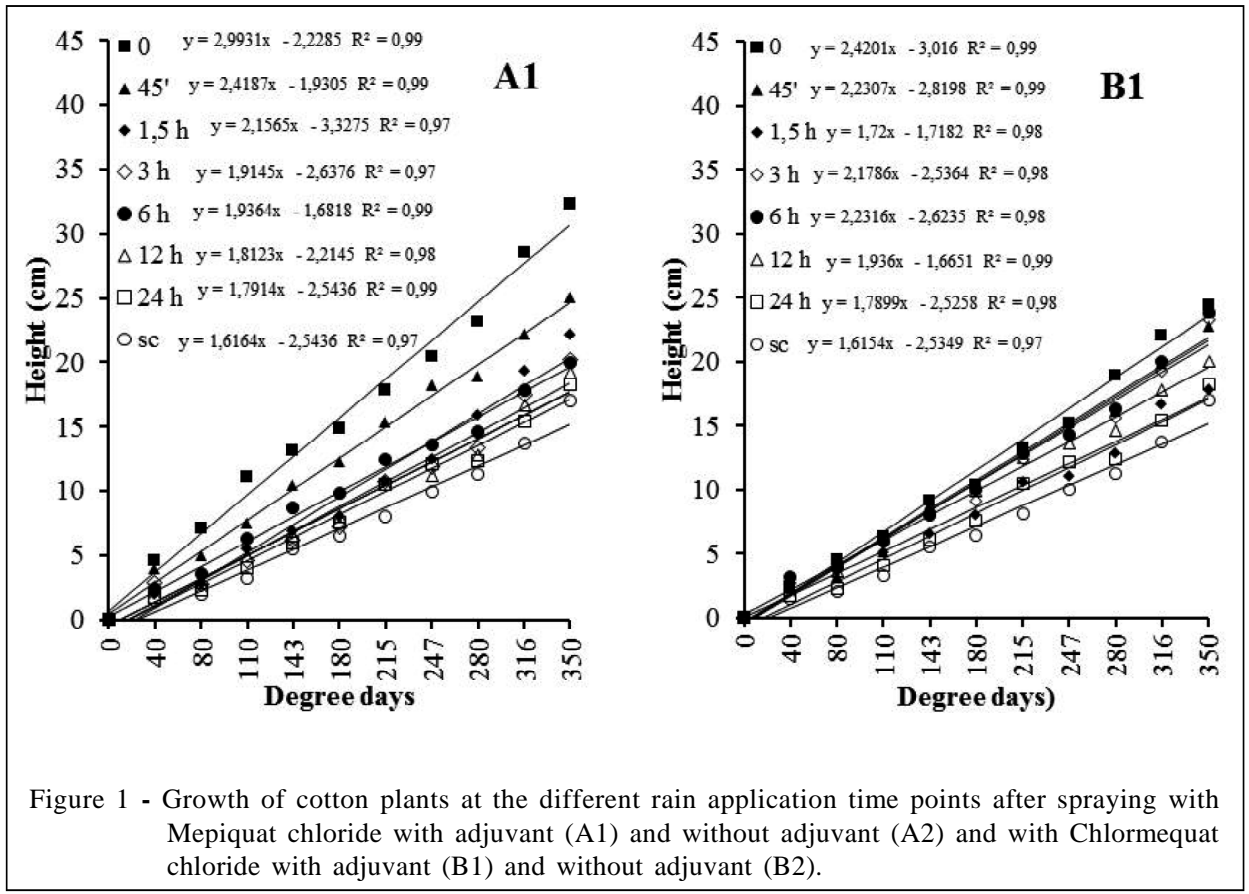

when the adjuvant was present, $\mathrm{CC}$ leaf concentrations were higher, showing that it had an important role in enhancing the effect of $\mathrm{CC}$ when rains were applied a short time after spraying (Figure 2B).

The adjuvant reduced plants' daily growth rates for both MC and $\mathrm{CC}$ (Figures 2C-D), and the decrease was more evident up to the sixth hour (360 minutes) from application, and so the need to replace regulators from this moment on was lower (Figures $2 \mathrm{E}$ F) because the PGR leaf concentrations were high enough (Figures 2A-B). The organic-silicon adjuvant improves solution penetration through the stomata because the resulting solution surface tension is very low, around $20 \mathrm{mN} \mathrm{m}^{-1}$ as compared with over $30 \mathrm{mN} \mathrm{m}^{-1}$ for conventional non organic-silicon adjuvants (ROSOLEM, 2002). Again, the adjuvant effect was

Table 3 - Final plant height at 350.8 degrees-day at the different rain application times after spraying with Mepiquat chloride and Chlormequat chloride - with and without adjuvant

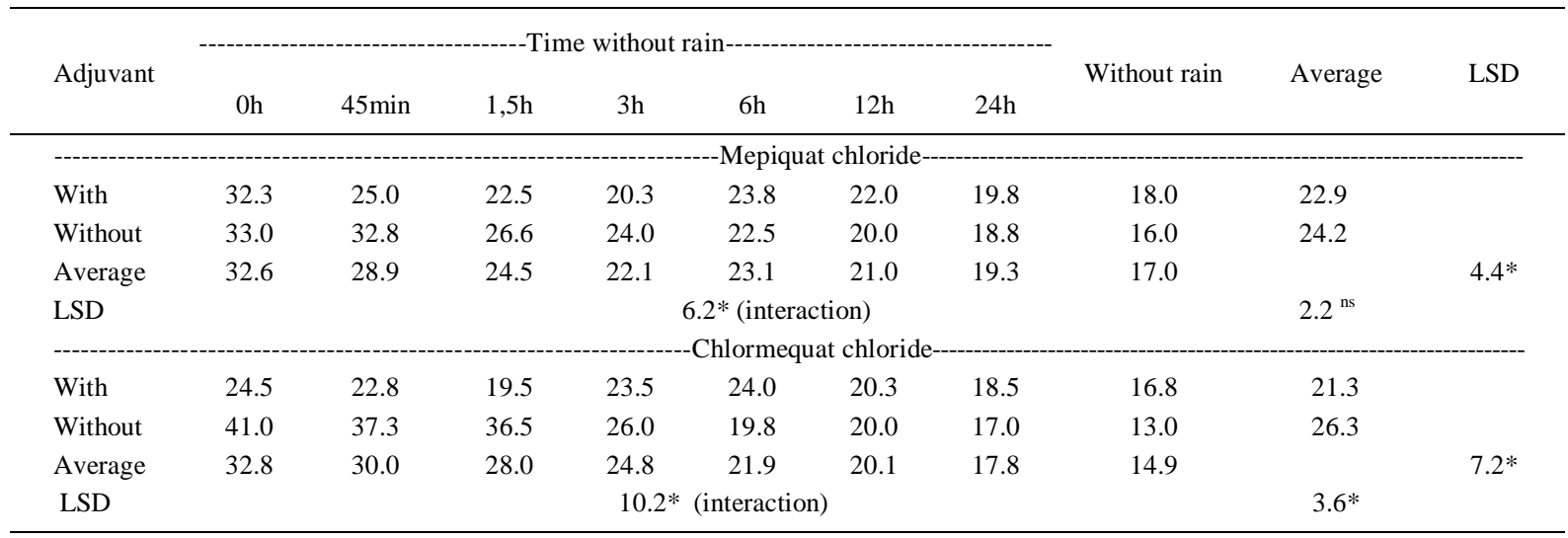

* LSD significant $(\mathrm{P}<0.05)$. ns: not significant 


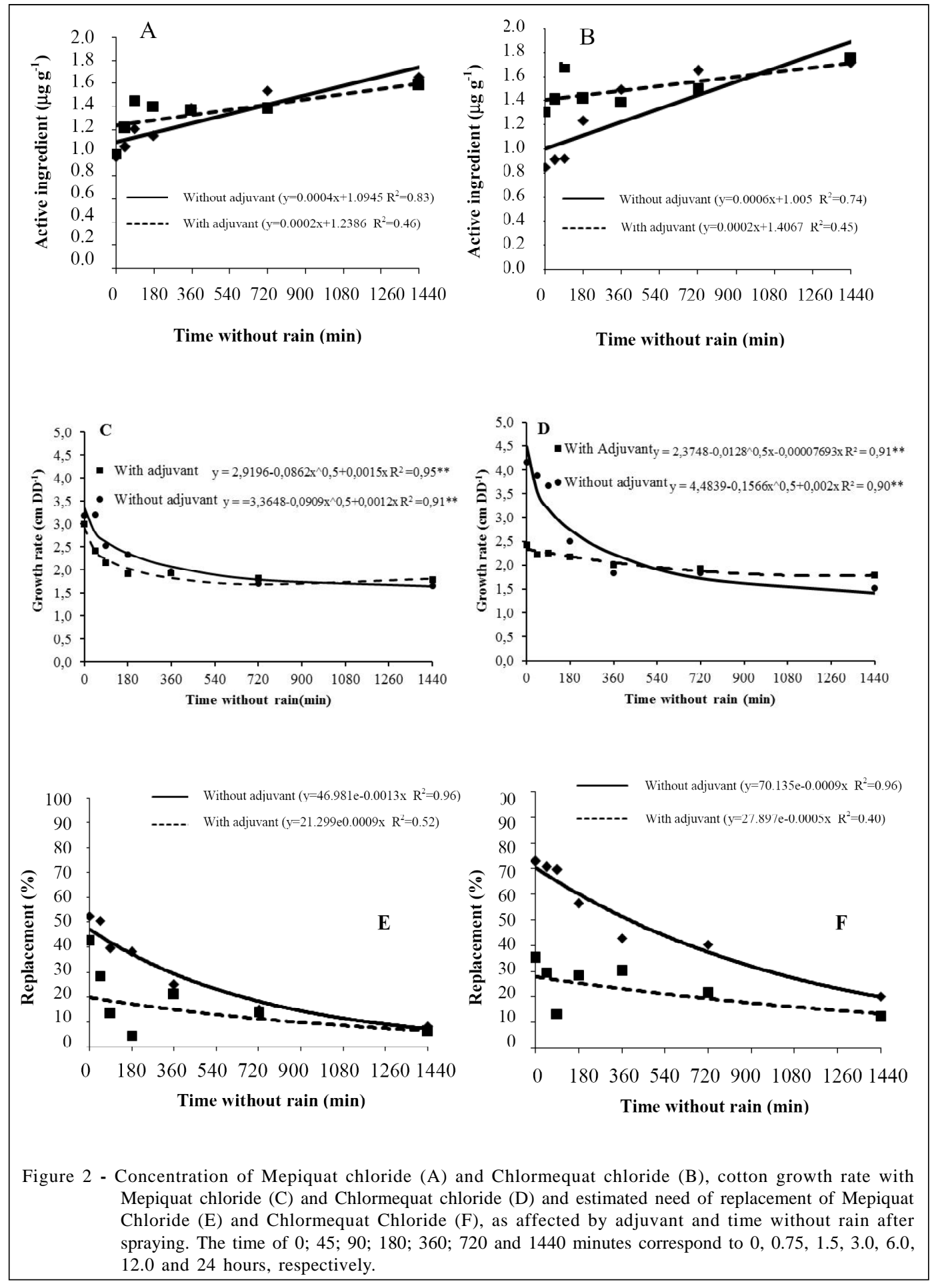

more noticeable in plants treated with CC, as these had smaller variations in growth rates as the time without rain increased. Lower plant growth rates were also observed by MATEUS et al. (2004) with MC, and by
GARCIA et al. (2010) with MC and CC without adjuvant, as the period without rain was increased.

The longer the time without rain after PGR application, the lower the rate that would have to be 
reapplied, both for MC (Figure 2E) and CC (Figure 2F). However, the amount of product that would have to be reapplied was different, ranging from 20 to $50 \%$ for $\mathrm{MC}$ and from 30 to $70 \%$ for $\mathrm{CC}$ when rain was applied right after spraying (0 hour). Hence, there was a difference between growth regulators, since rain occurring immediately after application resulted in a 55\% larger loss for CC. However, the use of a silicon adjuvant improved growth regulator uptake, reducing the need of reapplication by at least $50 \%$ up to $6 \mathrm{~h}$ without rain (Figures 1-B1 and 1-B2). Even when rain was applied 24 hours after spraying, there was a loss around 20\% when $\mathrm{CC}$ was applied without adjuvant, which was reduced to $10 \%$ in the presence of adjuvant. For MC, the adjuvant had no effect on the amounts to be replaced, which were lower than $10 \%$. Conversely, a study evaluating $\mathrm{MC}$ and $\mathrm{CC}$ losses on cotton showed higher losses for MC up to $6 \mathrm{~h}$ without rain (GARCIA et al., 2010). Using the same application rate used in this study (15g i.a ha ${ }^{-1}$ ), SOUZA \& ROSOLEM (2007) also observed that for a $30 \mathrm{~mm}$ rainfall $1.5 \mathrm{~h}$ after the application of MC without adjuvant, less than $13 \%$ of the dose applied would have to be re-applied.

\section{CONCLUSION}

The use of an organic-silicon adjuvant improves significantly, not only CC and MC uptake by cotton, but also their effect on plant growth. The occurrence of $30 \mathrm{~mm}$ of rain from immediately after spraying to 24 hours later can wash at least some the product off the cotton plants, and the amount washed is inversely proportional to the time without rain.

\section{REFERENCES}

BILES, S.P.; COTHREN, J.T. Flowering and yield response of cotton to application of Mepiquat chloride and PGR-IV. Crop Science, v.41 n.6, p.1834-1837, 2001. Available from: <https:/ /www.soils.org/publications/cs/abstracts/41/6/1834.doi:10.2135/ cropsci2001.183 >. Acesso em: 28 jul. 2011. doi: 10.2135/ cropsci2001.183.

COOK, D.R.; KENNEDY, C.W. Early flower bud and mepiquat chloride effects on cotton yield distribution. Crop Science, v.40, n.6, p.1678-1684, 2000.
FAO (FOOD AND AGRICULTURE ORGANIZATION OF THE UNITED NATIONS). World reference base for soil resources: world soil resources reports. Rome: FAO, 2006. n.103.

GARCIA, R.A. et al. Growth regulator losses from cotton plants due to rainfall. Scientia Agricola, v.67, n.2, p.158163, 2010. Available from: <http://dx.doi.org/10.1590/S010390162010000200005>. Acesso em: 22 jul. 2011. doi: 10.1590/ S0103-90162010000200005.

LAMAS, F.M. Estudo comparativo entre Mepiquat chloride e CC aplicados no algodoeiro. Pesquisa Agropecuária Brasileira, v.36, n.2, p.265-272, 2001. Available from: <http://www.scielo.br/ pdf/pab/v36n2/a08v36n2.pdf >. Acesso em: 26 jul. 2011.

MARUR, C.J.; RUANO, O. A reference system for determination of developmental stages of upland cotton. Revista de Oleaginosas e Fibrosas, v.5, n.2, p.313-317, 2001. Available from: <http://www.cnpa.embrapa.br/rbof/ artigos/522001002_rbof,5\%282\%29,313-17,2001.pdf >. Acesso em: 20 jul. 2011.

MATEUS, G.P. et al. Perdas de Mepiquat chloride no algodoeiro por chuva simulada. Pesquisa Agropecuária Brasileira, v.39, n.7, p.631-636, 2004. Available from: <http://dx.doi.org/10.1590/ S0100-204X2004000700003>. Acesso em: 26 jul. 2011.

RAIJ B.; VAN. et al. Análise química para avaliação da fertilidade de solos tropicais. Campinas: Instituto Agronômico, 2001. 285p.

REDDY, V.R. et al. Temperature and mepiquat chloride on cotton canopy architecture. Agronomy Journal, v.82, n.2, p.190-195, 1990. Available from: 〈https://www.soils.org/ publications/aj/abstracts/82/2/AJ0820020190>. Acesso em: 22 jul. 2011.

REDDY, A.R. et al. Mepiquat chloride (PIX) induced changes in photosyntesis and growth of cotton. Plant Growth Regulation, v.20, n.3, p.179-183, 1996. Available from: <http://www.springerlink.com/content/q866661889606160/>. Acesso em: 25 jul. 2011. doi: 10.1007/BF00043305.

ROSOLEM, C.A. Recomendações e aplicação de nutrientes via foliar. Lavras: Ufla/Faepe, 2002. 99p.

SOUZA, F.S.; ROSOLEM, C.A. Rainfall intensity and mepiquat chloride persistence in cotton. Scientia Agricola, v.64, n.2, p.125-130, 2007. Available from: <http://dx.doi.org/10.1590/ S0103-90162007000200004>. Acesso em: 25 jul. 2011. doi: 10.1590/S0103-90162007000200004.

ZHAO, D.; OOSTERHUIS, D.M. Pix plus and Mepiquat chloride effects on physiology, growth, and yield of field-grown cotton. Journal of Plant Growth Regulation, v.19, n.4, p.415-422, 2000. Available from: <http://www.springerlink.com/content/ 9x9kggf3gt2358r4>. Acesso em: 29 jul. 2011. doi: 10.1007/ s003440000018. 